\title{
Perlukah Kita Menggunakan Obat Kumur?
}

\author{
Nia Yuniarsih \\ Program Magister Farmasi, Fakultas Farmasi, Universitas Padjadjaran, Sumedang, 45363 \\ email: nia17003@mail.unpad.ac.id
}

\section{Abstrak :}

Obat kumur dapat digunakan untuk dua tujuan. Mereka bersifat terapeutik dan kosmetik. Bersifat terapeutik pada pembedahan mulut atau mencuci, untuk mengurangi plak, radang gusi, karies gigi, dan stomatitis.Surfaktan digunakan karena dapat membantu pelarut rasa dan menghilangkan kotoran dengan memberikan tindakan berbusa. Agen pembasah (wetting agent) didefinisikan sebagai senyawa yang mempunyai aktifitas permukaan (surface active agent) sehingga dapat menurunkan tegangan permukaan (surface tension) antara udara - cairan dan cairan - cairan yang terdapat dalam suatu sistem.Jadi obat kumur merupakan pembersih tambahan dan bukan pengganti. Pada akhirnya, obat kumur hanya berfungsi untuk "penyegar" mulut.

Keyword : obat kumur, radang, aktivitas permukaan, mulut

\section{Pendahuluan}

Mouthwashes atau Obat Kumur merupakan larutan yang digunakan sebagai pembersih mulut atau pengobatan penyakit dari membran mukosa mulut, Obat kumur memberi rasa dan bau yang menyenangkan untuk beberapa lama setelah berkumur.

Mouthwashes merupakan larutan berair sering dalam bentuk terkonsentrasi yang mengandung satu atau lebih bahan aktif atau eksipien digunakan dengan memutar cairan di rongga mulut.

\section{Fungsi obat kumur}

Obat kumur dapat digunakan untuk dua tujuan. Mereka bersifat terapeutik dan kosmetik. Bersifat terapeutik pada pembedahan mulut atau mencuci, untuk mengurangi plak, radang gusi, karies gigi, dan stomatitis. Sementara

Obat kumur kosmetik dapat diformulasikan untuk mengurangi bau mulut melalui penggunaan agen antimikroba dan / atau memberikan rasa segar. Pada umumnya Obat kumur dibuat dengan bahan dasar air. Kebanyakan produk dapat menjadi sempurna dalam campuran bahan dasar padat atau cair dicampurkan dengan air sebelum digunakan.

\section{Kandungan dalam obat kumur}

Komposisi Obat kumur dibagi 2 yaitu bahan aktif dan bahan tambahan, bahan tambahan terdiri dari : 


\section{Alkohol}

Fungsi alkohol dalam sediaan Obat kumur:

1) Untuk menambah kelarutan minyak wangi dan campuran organik lainnya, yang kelarutannya kurang dalam air.

2) Mengurangi gaya tegangan permukaan, sebagai pembasah, penetrasi, aksi bahan antibakteri dan menghilangkan bau.

3) Bertindak sebagai astrigen, dengan mengikat air dan mengubah sifat protein didalamnya.

\section{Surfaktan}

Surfaktan (Surface Active Agent) yang berarti bahan aktif permukaan. Surfaktan merupakan bahan yang dapat menurunkan tegangan permukaan.

Dalam penggunaannya surfaktan dapat berfungsi sebagai bahan pembasah (Weiting Agent), pengemulsi (Emulsifying Agent), bahan pencegah terbentuknya busa (Antifoaming Agent) dan juga sebagai bahan pembantu pelarutan (Solublizing Agent) atau menormalkan bahan isi yang tidak larut dalam air (Balsam M.S ,1972).

Macam - macam surfaktan yang sering digunakan dalam sediaan farmasi antara lain :

Anionik, yaitu surfaktan yang bagian alkilnya terikat pada suatu anion, contohnya Alkyl benzene Sulfonate (ABS), Linear Alkyl Sulfonate (LAS), Alpha Olein Sulfonate (AOS)

Kationik yaitu surfaktan yang bagian alkilnya terikat pada suatu kation, contohnya garam ammonium

Nonionik yaitu surfaktan yang bagian alikilnya tidak bermuatan, contoh ester gliserin asam lemak, ester sukrosa asam lemak

Amfoter yaitu surfaktan yang bagian alkiknya mempunyai muatan positif dan negative, contohnya surfaktan yang mengandung asam amIN9.

\section{Pemanis}

Pemberi rasa dimaksudkan untuk menutupi rasa obat yang tidak diinginkan. Pemanis digunakan untuk memberikan rasa manis pada suatu sediaan obat. Bahan pemanis biasanya atau tidak selamanya digunakan dalam obat kumur. Pemanis terbagi 2 (dua) yaitu pemanis alami seperti sukrosa, manitol, glyserin, caramel, sorbitol, dan pemanis buatan (sintetik) seperti sodium sakarin dan sodium siklamat.

\section{Pewarna}

Pewarna digunakan untuk menambah daya tarik dari suatu sediaan obat. Umumnya digunakan zat warna yang berhubungan dengan pemberi rasa yang digunakan dan tidak mengganggu kemanjuran terapi produk.

Zat warna ditambahkan kedalam preparat farmasi dalam bentuk larutan encer bukan sebagai serbuk kering. Dalam memilih zat warna untuk penggunaan dalam suatu sediaan farmasi cairan adalah $\mathrm{pH}$ dan $\mathrm{pH}$ kestabilan dan preparat yang akan diberi warna. 
Zat warna dapat mengubah warna dengan suatu perubahan dalam $\mathrm{pH}$, dan suatu zat warna harus dipilih untuk suatu produk sehingga suatu perubahan $\mathrm{pH}$ yang diharapkan tidak akan mengubah warna selama penyimpanan.

Zat warna harus stabil secara kimia dalam lingkungan bahan formulasi dan tidak boleh menggangu kestabilan zat lain.

Zat warna juga harus stabil terhadap cahaya berarti zat warna tidak boleh berubah warna jika dipaparkan ke cahaya dalam waktu yang lama, zat obat yang dibuat dalam bentuk cairan harus dilindungi dari cahaya untuk menjaga kestabilan kimianya dan keefektifan terapinya. Pewarna yang digunakan umumnya larut dalam air, tidak bereaksi dengan komponen lain dari sediaan obat dan warnanya stabil pada kisaran pH.( Balsam Ms, 1972 ; Ansel, 1989)

\section{Mekanisme obat kumur}

Surfaktan digunakan karena dapat membantu pelarut rasa dan menghilangkan kotoran dengan memberikan tindakan berbusa. Agen pembasah (wetting agent) didefinisikan sebagai senyawa yang mempunyai aktifitas permukaan (surface active agent) sehingga dapat menurunkan tegangan permukaan (surface tension) antara udara - cairan dan cairan - cairan yang terdapat dalam suatu sistem.

Kemampuannya menurunkan tegangan permukaan menjadi hal yang menarik karena agent pembasah memiliki keajaiban struktur kimia yang mampu menyatukan dua senyawa yang berbeda polaritasnya.

Surfaktan merupakan zat aktif permukaan yang mempunyai 2 ujung yang berbeda yaitu kepala hidrofilik memiliki afinitas terhadap air dan ekor hidrofobik terhadap minyak. Zat aktif ini yang berfungsi menurunkan tegangan permukaan sehingga dapat melepaskan minyak atau kotoran yang terdapat pada sela-sela gigi dimana kotoran ini tersusun dari unsure $\mathrm{C}$ dan $\mathrm{H}$. pada awalnya surfaktan membentuk misel dengan ujung hidrofil berikatan hydrogen dengan air, sedangkan ujung hidrofobnya tertolak oleh air. Saat berdekatan dengan kotoran (mengandung unsure $\mathrm{C}$ dan $\mathrm{H}$ ) ujung hidrofob akan menarik kotoran dan membentuk misel baru, sehingga kotoran dapat ditarik.

Surfaktan dapat memperkecil sudut kontak antara partikel zat padat dan larutan pembawa. Surfaktan kationik dan anionik efektif digunakan untuk bahan berkhasiat dengan zeta potensial positif dan negatif. Sedangkan surfakatan nonionik lebih baik untuk pembasah karena mempunyai range $\mathrm{pH}$ yang cukup besar dan mempunyai toksisitas yang rendah. Konsentrasi surfaktan yang digunakan rendah karena bila terlalu tinggi dapat terjadi solubilisasi, busa dan memberikan rasa yang tidak enak.

Namun, perlu diingat, alkohol bisa membuat mulut kering dan kekurangan cairan. Jadi, lebih baik pilih obat kumur tanpa alkohol jika Anda memiliki masalah mulut kering dan bau.

Jadi obat kumur merupakan pembersih tambahan dan bukan pengganti, , kita harus tetap menyikat gigi dan mengecek kondisi gigi ke dokter setiap enam bulan sekali. Pada akhirnya, obat kumur hanya berfungsi untuk "penyegar" mulut. Sebenarnya, kita tidak membutuhkannya, namun jika Anda merasa memiliki masalah bau mulut, tidak ada salahnya menggunakan obat kumur sekali dalam sehari. 


\section{Daftar Pustaka}

Ansel H.C, 1989, Pengantar Bentuk Sediaan Farmasi, edisi IV, Penerbit Universitas Indonesia.

Arhur, H. Kibbe, PH. D, 2000, Pharmaceutical Excipients, American Pharmaceutical Association, Washington DC.

Balsam, M.S, 1972, Cosmetic Science and Technology Second Edition. London

http://nationalgeographic.co.id/berita/2016/03/perlukah-kita-menggunakan-obat-kumur di akses pada 13 Desember 2017. 